\title{
Subaqueous melt rates at calving termini: a laboratory approach
}

\author{
Kim Jardine EiJPEN, Gharles R. WARREN, Douglas I. BENN \\ School of Geography and Geosciences, University of St Andrews, St Andrews, Fife Kr16 9AL, Scotland \\ E-mail:kj9@st-andrews.ac.uk
}

\begin{abstract}
Numerous field and theoretical studies have pointed to an important role for subaqueous and waterline melting in the dynamics of calving glaciers. These processes remain unquantified because of the dangerous nature of the environment, a data gap which hampers both theoretical and numerical modelling studies. Here we report laboratory experiments designed to quantify waterline and subaqueous ice-melt rates in saline and fresh water. Experiments were conducted at temperatures of $1-10^{\circ} \mathrm{C}$, a range typical of ice-contact environments, and at salinities of $0,17.5$ and 35 ppt. Results indicate that melt rates are slightly faster under fresh-water conditions, and that different thermohaline combinations can produce contrasting ice-front geometries. Thermo-notches develop quickly at higher temperatures $\left(>4^{\circ} \mathrm{C}\right)$, and form most rapidly and to a greater extent in saline water. Contrasts in melt rates and ice-front geometry are controlled by temperature-driven density contrasts and circulation patterns. Rates of up to $0.8 \mathrm{~m} \mathrm{~d}^{-1}$ suggest that mass loss by subaqueous melting is a significant process at calving termini.
\end{abstract}

\section{INTRODUGTION AND BAGKGROUND}

It has long been assumed that, at the termini of calving glaciers, mass is lost primarily through mechanical means rather than by melting. However, it is becoming increasingly apparent that melting, both subaerial and subaqueous, is a significant ablation process at calving termini, but one about which remarkably little is known (Kirkbride and Warren, 1997; Hanson and Hooke, 2000; Motyka and others, 2003). Calving rates in tidewater consistently exceed those in fresh water by an order of magnitude for reasons that are incompletely understood (Warren and others, 1995b; Van der Veen, 2002; Warren and Kirkbride, 2003). Funk and Röthlisberger (1989) suggest that differences in the buoyancy of meltwater may be the connection, the much greater buoyancy in salt water possibly accelerating subaqueous melting and in turn enhancing calving. This implies a link between subaqueous and/or waterline melting and calving. Ambient water conditions at the waterline and along subaqueous portions of the ice front may indeed be important, as postulated by Kirkbride and Warren (1997) and Purdie and Fitzharris (1999). For example, Meier and others (1985) document evidence from Columbia Glacier, Alaska, U.S.A., which indicates that maximum calving rates coincide with high subglacial meltwater discharge, implying that ice-proximal subaqueous processes may affect calving dynamics, and it is likely that large quantities of meltwater will exacerbate melting along the ice face through buoyant, turbulent forcing. However, given the dangerous nature of such places, laboratory simulations offer a safe, feasible way of obtaining empirical melt-rate data for the range of temperatures and salinities encountered in field settings. Here we report laboratory investigations of the effects of varying temperature and salinity on subaqueous ice-melt rates.

The few previous studies of waterline and subaqueous melt rates have focused on the viability of towing tabular icebergs in relatively warm $\left(>18^{\circ} \mathrm{C}\right)$ saline water (Weeks and Campbell, 1973; Mathews and Quinlan, 1975; Josberger and Neshyba, 1980; Russell-Head, 1980). Their relevance to icecontact calving environments is therefore limited. Josberger (1978) and Russell-Head (1980) demonstrate a linear relationship between temperature and melting in a sea-water environment. At $10^{\circ} \mathrm{C}$ in water varying from 0 to $35 \mathrm{ppt}$ salinity, Russell-Head finds that melting is slightly faster in fresh water, that little difference exists between 17.5 and $35 \mathrm{ppt}$, and that salinity is a greater influence on water density than temperature. To our knowledge, no previous studies have compared melting at varying salinities at the low temperatures typical of calving environments. Because of abundant inputs of meltwater, salinities in the ice-proximal zone of temperate tidewater fronts rarely approach 35 ppt but more typically fluctuate around half this value (personal communication from R. D. Powell, 2001)

\section{EXPERIMENTAL METHOD}

The experiments were carried out in a temperature-controlled laboratory. Distilled water was frozen at a temperature of $-15^{\circ} \mathrm{C}$ in stainless-steel moulds measuring $35 \mathrm{~cm}$ high $\times 15 \mathrm{~cm}$ wide $\times 5 \mathrm{~cm}$ deep. At the start of each experimental run, the ice blocks were at a temperature of $-15^{\circ} \mathrm{C}$. Three glass tanks, $90 \mathrm{~cm}$ long $\times 37 \mathrm{~cm}$ high $\times 30 \mathrm{~cm}$ wide, were filled with $54 \mathrm{~L}$ of distilled water, filling the tank to half-capacity. Pure $\mathrm{NaCl}$ was mixed into two of the tanks to provide one solution of $17.5 \mathrm{ppt}$ salinity and another of $35 \mathrm{ppt}$ salinity, simulating sea water. Salinities were checked using a Pinpoint Salinity Monitor. The third tank was filled with fresh water. The water temperature was controlled by the ambient temperature of the cold laboratory. 


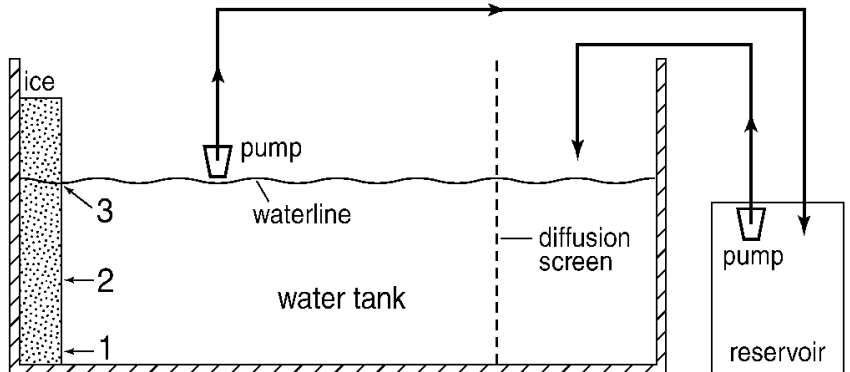

Fig. 1. Schematic diagram of the experimental set-up.

Each ice block was secured flush with the glass at one end of a tank with half of the height $(\sim 17.5 \mathrm{~cm})$ submerged, allowing subaerial and subaqueous melt rates to be measured (Fig. 1). Constant temperature and salinity was maintained via a thermal exchange arrangement driven by small aquarium pumps. This involved continuously pumping the surface water out of the experimental tank at a rate of $300 \mathrm{Lh}^{-1}$, along a $1 \mathrm{~m}$ long, low-gradient open pipe, and into a separate $9 \mathrm{~L}$ reservoir. Here water temperature would re-equilibrate before being pumped into the far end of the experimental tank. Water being returned to the experimental tank was within $1{ }^{\circ} \mathrm{C}$ of the initial temperature. A Perspex diffusion screen prevented any forced convection. An identical experimental set-up was adopted in each of the three tanks.

Melt rates were measured at five points using acrylic rules fixed to the side of each glass tank: two below the waterline (location 1 at $0 \mathrm{~cm}$ and location 2 at $8 \mathrm{~cm}$ above the base of the ice face), one at the waterline (location 3 at $15 \mathrm{~cm}$ ) and two above (location 4 at $22 \mathrm{~cm}$ and location 5 at $32 \mathrm{~cm}$ ) (Fig. 1). This allowed contrasts in melt rates and circulation patterns to be located more precisely than in previous laboratory studies, where measurements were taken at a single location and the melt rate was then averaged over the entire face. Experiments were conducted at $1^{\circ}, 2^{\circ}, 4^{\circ}, 6^{\circ}, 8^{\circ}$ and $10^{\circ} \mathrm{C}$. The length of the run varied with temperature from 1 to 6 hours, with 8-10 measurements per run. Three runs for each temperature/salinity combination were completed and the data averaged. At the time of each measurement, water temperatures were recorded in the upper and lower parts of the water column in both ice-proximal and far-field locations using a Hanna Checktemp 1 Thermometer accurate to $\pm 0.3^{\circ} \mathrm{C}$. To make circulation patterns clearly observable, Iriodin 522 was added to the water and a bright light was directed through the tank along the ice face. The ferrous oxide-coated mica particles $(5-25 \mu \mathrm{m})$ remained in suspension throughout each melt run, allowing visual monitoring of convection patterns.

\section{RESULTS}

\section{Dependence of melt rate on salinity and temperature}

Figure 2 illustrates subaqueous melt-rate data over the three different salinities, at temperatures ranging from $1^{\circ}$ to $10^{\circ} \mathrm{C}$. Subaerial rates (not illustrated) exhibit uniform change with temperature. Subaqueous melt rates vary only slightly with changing salinity, although slightly faster melting occurs in fresh water, especially along the lower portions of the ice (Fig. 2c and d). At the waterline, melt rates are highest in sea water at $8^{\circ} \mathrm{C}$, and in half-salinity water at $10^{\circ} \mathrm{C}$. a

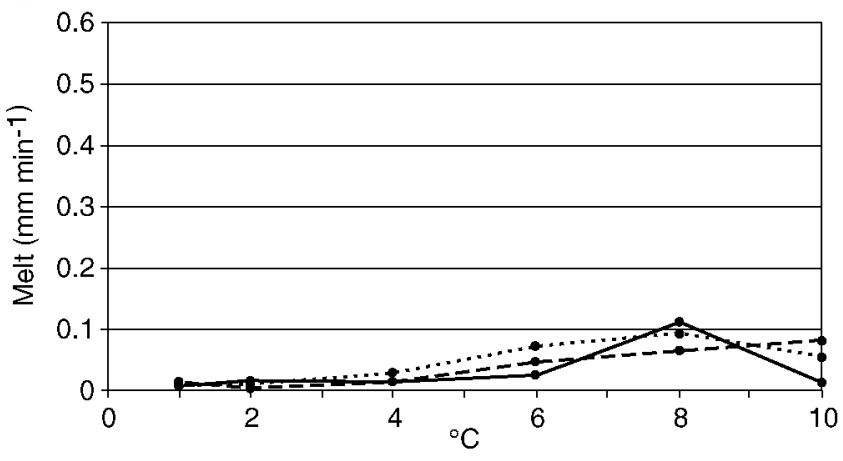

b

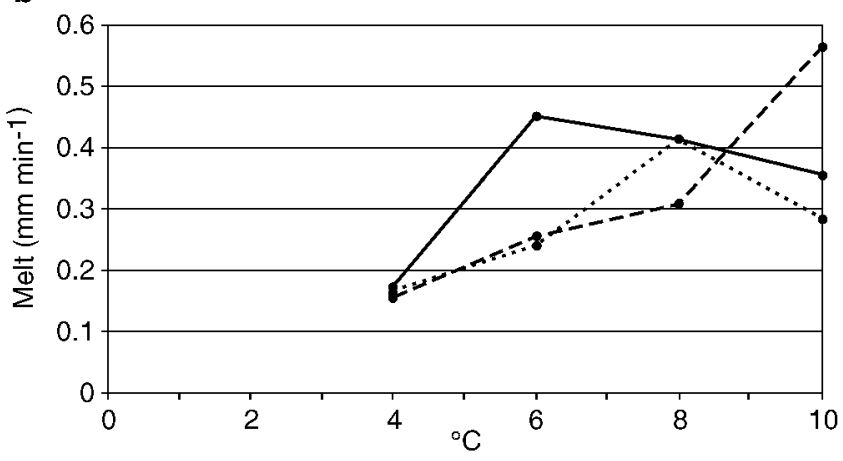

c

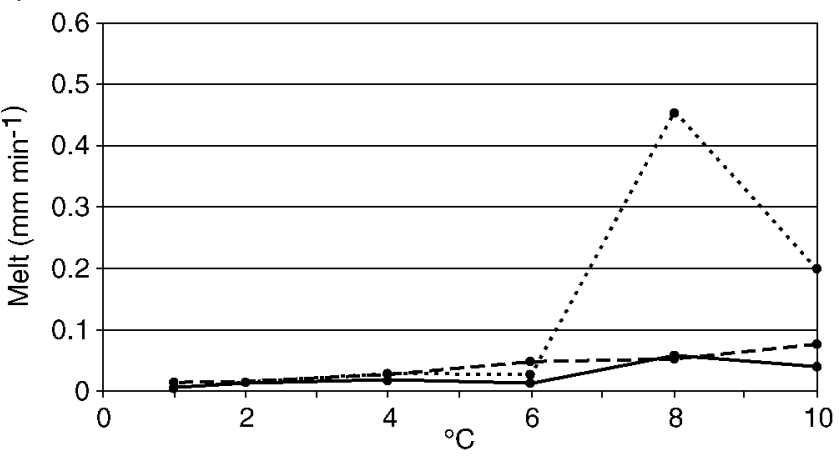

d

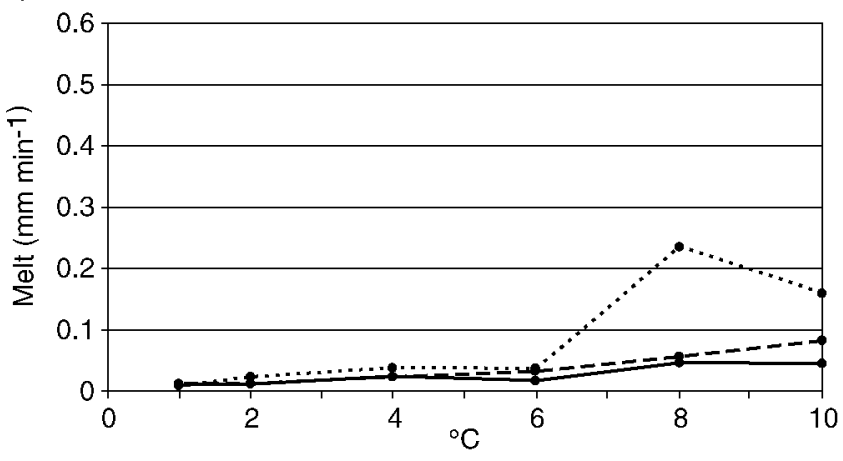

Fig. 2. Melt rates at different temperatures across the three salinities. (a) Melting at location 3 (the waterline). (b) Melting directly below the waterline. Notch development did not occur below $4^{\circ}$ C. (c) Melting at location 2. (d) Melting at location 1 (the base of the ice face).

Below this temperature, melting is fastest in fresh water. In all salinities, melting is concentrated directly beneath the waterline, where a sub-horizontal thermo-erosional notch typically develops at temperatures $\geq 4^{\circ} \mathrm{C}$ but not in cooler water. At $8^{\circ} \mathrm{C}$ and above, notches develop within 10-20 min (Fig. 2b). In water of 17.5 ppt salinity, melting increases with temperature to a maximum of $0.56 \mathrm{~mm} \mathrm{~min}^{-1}$, whereas in sea water melt rate increases to a peak of $0.45 \mathrm{~mm} \mathrm{~min}^{-1}$ at $6^{\circ} \mathrm{C}$ and then decreases with further increases in tempera- 

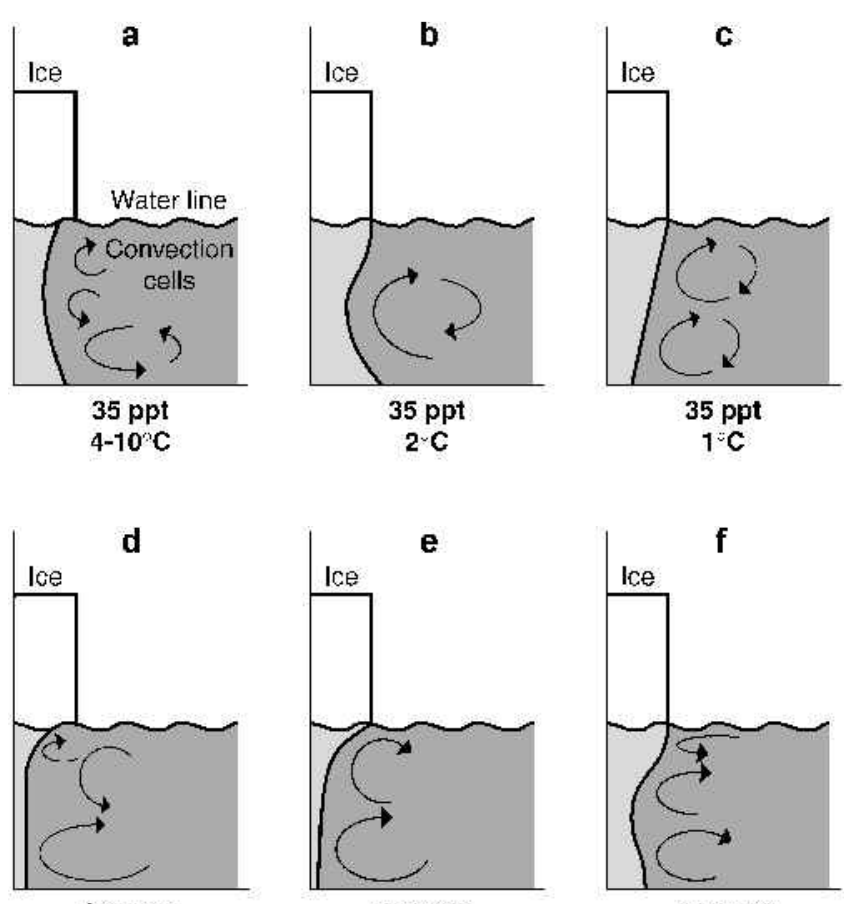

$17.5 \mathrm{ppt}$

6-10 c
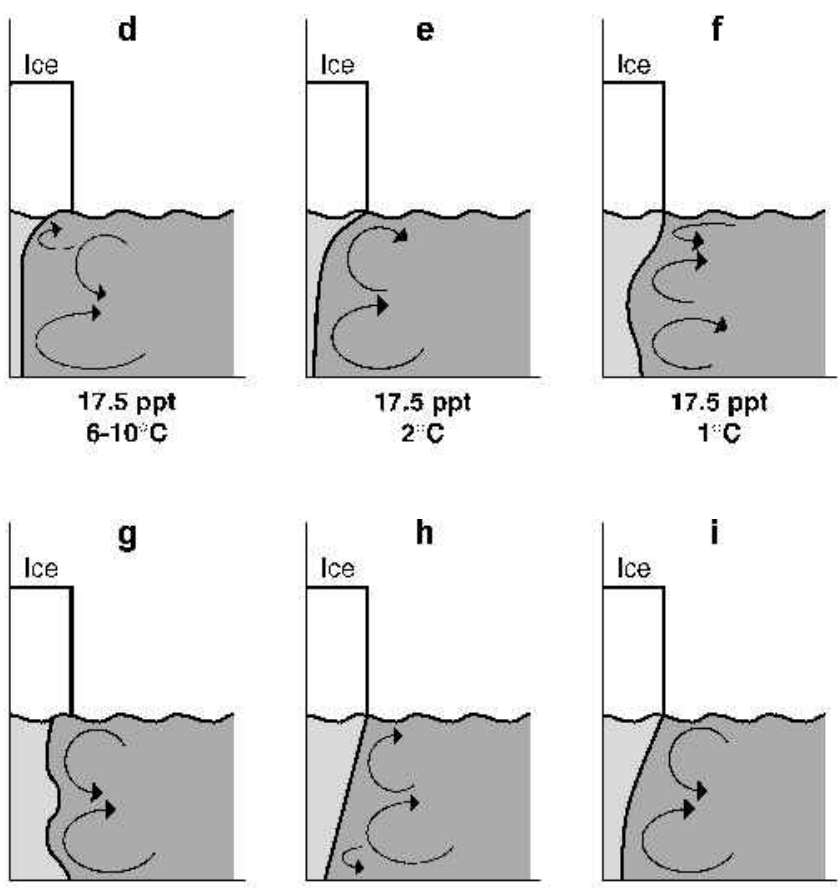

Fresh water

4-10 C

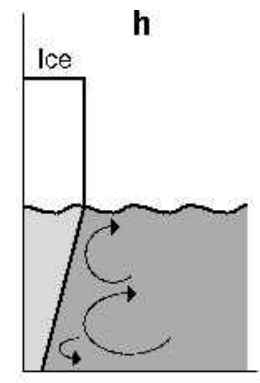

Fresh water

$2 \mathrm{C}$

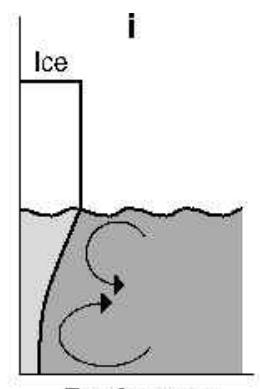

Fresh water

$1: \mathrm{C}$

Fig. 3. Schematic diagrams of convection cell circulation.

ture. The pattern in fresh water is similar but with a peak of $0.41 \mathrm{~mm} \mathrm{~min}^{-1}$ at $8^{\circ} \mathrm{G}$, before decreasing with increasing temperature.

At the base of the ice block (position 1, Fig. 2d), melt rates in all salinities are closely similar and increase with temperature below $6^{\circ} \mathrm{C}$. Above this temperature, melt rates in fresh water increase rapidly, peak at $8^{\circ} \mathrm{C}$ and then decrease. At position 2 (Fig. 2c), the situation is similar, with melting in fresh water reaching a maximum of $0.45 \mathrm{~mm} \mathrm{~min}^{-1}$ at $8^{\circ} \mathrm{C}$. Melt rates in sea water also peak at $8^{\circ} \mathrm{C}$, whereas melt rates in half-salinity water increase steadily with temperature to a maximum at $10^{\circ} \mathrm{C}$. At temperatures $\leq 4{ }^{\circ} \mathrm{C}$ at both of these positions, melt rates between the three salinities are closely similar.

Melting patterns are most variable directly beneath the waterline (position 3, Fig. 1). At the waterline itself (Fig. 2a), melting in half-salinity water increases with warming temperatures, and it is in this water that highest melting is found at $10^{\circ} \mathrm{C}$. Both saline and fresh water again reach a peak melt rate at $8^{\circ} \mathrm{C}$, with saline water having slightly higher ice-melting rates. Melt rates are fastest in fresh water at $4-6^{\circ} \mathrm{C}$; below this temperature, melt rates are similar across all the water types. Throughout the experimental

runs, far-field water temperatures were consistently $\geq 1{ }^{\circ} \mathrm{C}$ above those found in the ice-proximal zone.

\section{Subaqueous geometry and circulation at the ice face}

Consistent subaqueous geometries develop during each icemelt run, reflecting contrasting circulation patterns (Fig. 3). In all salinities, the circulation patterns fall into three distinct temperature-dependent groups: $1^{\circ}, 2^{\circ}$ and $4-10^{\circ} \mathrm{C}$. The only exception is at $4^{\circ} \mathrm{C}$ in half-salinity water where circulation consisted of a single upward-moving convection cell. In sea water a notch quickly develops at and beneath the waterline between $4^{\circ}$ and $10^{\circ} \mathrm{C}$, and melting is faster at location 2 than at location 1 or 3 (Fig. 1). This area of faster melting is concentrated at the top of a large convection cell at the base of the ice wall (Fig. 3a). At $1^{\circ} \mathrm{C}$ there is a melt maximum at location 1 . At $2^{\circ} \mathrm{C}$ an intermediate situation obtains in which melting is fastest at location 2 but not as fast as at temperatures $>4{ }^{\circ} \mathrm{C}$; a single convection cell draws water in at the base.

By contrast, at $17.5 \mathrm{ppt}$ salinity and at temperatures above $1{ }^{\circ} \mathrm{C}$, melting is concentrated at location 1 (Fig. $3 \mathrm{~d}$ and e), causing a slight overhang at the water surface. At $1^{\circ} \mathrm{C}$, melting is focused at location 2 , where a central cell of convection is concentrated (Fig. 3f), and a slight protrusion at the base of the ice is evident. There is little waterline melting at $4^{\circ} \mathrm{C}$ (not illustrated); circulation consists of a single clockwise cell which did not extend to the waterline. In fresh water, a projection in the middle of the ice face at $4-10^{\circ} \mathrm{C}$ occurs at the junction of two distinct convection cells (Fig. $3 \mathrm{~g}$ ), with minimum melting at location 2. At lower temperatures, melting is fastest at the base of the ice, where convection is most vigorous (Fig. $3 \mathrm{~h}$ and i). A zone of accreted ice formed at the waterline in all salinities at temperatures of $1^{\circ}$ and $2{ }^{\circ} \mathrm{C}$. This usually developed within 1 hour and was of the order of a few millimetres thick and sometimes exceeded $8 \mathrm{~mm}$ in thickness. At $4^{\circ} \mathrm{C}$, slushy layers developed at the waterline in all salinities, but these did not persist. Curiously this slush was evident in sea water at all temperatures.

\section{DISGUSSION AND GONGLUSIONS}

The experimental results show that melt rates are not simply proportional to water temperature. This clearly illustrates the importance of circulation patterns in modulating melting at a submerged ice face. The greatest variability in melt rates occurs at and just beneath the waterline, reflecting the more complex circulation patterns in these locations. In all cases, areas of maximum ice melt correspond with convection cell development and location. This is especially apparent in fresh water at $4-10^{\circ} \mathrm{C}$. It appears that, at each salinity measured, temperature-driven density contrasts explain the convection patterns, and that convection is advecting the warmer farfield water to the ice face, thus delivering more energy for melting. At each temperature/salinity combination at and above $4^{\circ} \mathrm{C}$ (the density extremum in fresh water), circulation patterns are stable and consistent. In sea water, Josberger (1978) reports bidirectional flow occurring in the boundary layer of melting ice, where an upward-moving turbulent flow regime is separated midway down the ice face by a downward-moving laminar region. This study reveals a similar pattern, particularly at temperatures above $2{ }^{\circ} \mathrm{C}$ (Fig. 3a). Russell-Head (1980) also reports differing melt patterns in 
fresh and saline water, but does not specify what these geometric differences are.

Our experiments replicated the development of thermoerosional notches close to the waterline, similar to those described at slow-flowing calving termini (Kirkbride and Warren, 1997; A. Vieli and others, unpublished information). In the experiments, rapid melting in saline water occurs at 4- ${ }^{\circ} \mathrm{C}$, temperatures commonly found both in ice-contact lake environments and in the boundary layer in tidewater situations (Warren and Kirkbride, 1998; personal communication from R.Powell, 2001). Melting at and near the waterline is over twice as fast as at other locations, indicating a maximum melt rate of $0.8 \mathrm{~m} \mathrm{~d}^{-1}$. A similar rate of $0.89 \mathrm{~m} \mathrm{~d}^{-1}$ at $10^{\circ} \mathrm{C}$ is reported by Russell-Head (1980). Weeks and Campbell (1973) propose an equation for calculating ice-melt rates at different water temperatures and current speeds, and this has sometimes been used to calculate melt rates along the subaqueous parts of calving termini. Our results, however, suggest that this equation may yield rates which are unrealistically low. For example, using the Weeks and Campbell equation, Hunter and others (1996) calculate melt rates of just $0.05-0.08 \mathrm{~m} \mathrm{~d}^{-1}$ at Alaskan tidewater glaciers. Given that the high rates reported here and from previous laboratory studies occur in the absence of forced convection by meltwater upwelling, these findings support the suggestion made by Hanson and Hooke (2000) that subaqueous melting may be of greater magnitude and significance than previously anticipated.

The observations of ice accretion and slushy ice in saline water across the temperature spectrum can be attributed to heat conduction from the ambient water to the (cold) ice as it warms to $0^{\circ} \mathrm{C}$. This explains why the slush is maintained for only a short time ( $<20 \mathrm{~min}$ ) at higher temperatures. In the saline-water experiment, this slush affords some protection to the waterline, reducing melt rates.

The lack of notch development below $4{ }^{\circ} \mathrm{C}$ is unexpected since thermo-erosional notches have been observed at calving glaciers at temperatures of $\leq 0.5^{\circ} \mathrm{C}$ (Purdie and Fitzharris, 1999; Warren and others, 2001). It is likely that the scale of the laboratory experiments explains this anomaly. Longer runs with thicker ice blocks might have allowed erosional notches to develop at $1^{\circ}$ and $2^{\circ} \mathrm{C}$. Ice accretion at the waterline in cooler water also inhibited notch development.

The scale and configuration of the observed circulation patterns are likely to differ substantially from those found in the field, implying that the melt rates reported here should not be simply applied to real water-terminating glaciers. The results do, however, indicate that circulation patterns are of similar importance to temperature in determining subaqueous melting, and that density contrasts are likely to be the most important drivers of such circulations.

Discussions of calving processes have paid little attention to waterline and subaqueous processes until recently, despite the fact that such processes may significantly affect mechanical calving (Kirkbride and Warren, 1997; Purdie and Fitzharris, 1999; Hanson and Hooke, 2000). At lakecalving termini, for example, there is a positive correlation between calving rates and water temperature (Warren and Kirkbride, 2003), and rapid subaqueous melting has been suggested as an explanation for the fact that calving rates in tidewater are consistently faster than those in fresh water (Funk and Röthlisberger, 1989). Intuitively, then, faster melt rates might be expected in saline water, but the results reported here show generally faster melt rates in fresh water.
Russell-Head (1980) also reports slightly higher melt rates at $10^{\circ} \mathrm{C}$ in fresh water than in saline water, with absolute melt rates directly comparable with the findings of this study $\left(1.2 \mathrm{~m} \mathrm{~d}^{-1}\right.$ in fresh water and $0.89 \mathrm{~m} \mathrm{~d}^{-1}$ in $35 \mathrm{ppt}$ solution). Perhaps the two most relevant water chemistries are fresh water and intermediate salinity given that salinity in the subaqueous boundary layer at tidewater fronts will be much reduced through mixing with upwelling meltwater. For example, in the upper $10 \mathrm{~m}$ of the water column at Grand Pacific Glacier, Alaska, salinity is typically of the order of 11-18 ppt (personal communication from R. Powell, 2001). Warren and others (1995a) also report half-salinity conditions at Glacier San Rafael, Chile. Both sets of laboratory simulations included free convection only, whereas vigorous forced convection driven by copious inputs of meltwater is typical at calving termini. This can be expected to increase melt rates significantly by advecting warm far-field water to the ice face, especially at tidewater glaciers because meltwater is 200 times more buoyant in sea water than in fresh water. Given that the experiments demonstrate that melt rates are strongly modulated by circulation patterns, it is probable that vigorous water circulation and rapid subaqueous melting is one of the factors that promote rapid calving at tidewater glaciers (cf. Motyka and others, 2003). Such circulation patterns are driven partly by meltwater upwelling and partly by density contrasts between meltwater and ambient water.

The main findings are:

Temperature-driven density contrasts drive convection in all salinities, concentrating melting at particular locations along the ice face. The resulting contrasts in melt rate and ice-front geometry may be important when considering subaqueous melting as a rate-controlling mechanism of glacier calving.

Free convection produces maximum melt rates of 0.65 $0.8 \mathrm{~m} \mathrm{~d}^{-1}$ in fresh water, sea water and in half-saline water. Given that forced convection associated with meltwater upwelling is the norm at calving fronts, these represent minimum values, indicating that subaqueous melting is an important process at calving fronts.

\section{AGKNOWLEDGEMENTS}

This work was carried out whilst in receipt of a grant from the Carnegie Trust for the Universities of Scotland. Detailed input from B. Hanson, E. Rignot and E. Cowan considerably improved the manuscript.

\section{REFERENGES}

Funk, M. and H. Röthlisberger. 1989. Forecasting the effects of a planned reservoir which will partially flood the tongue of Unteraargletscher in Switzerland. Ann. Glaciol., 13, 76-81.

Hanson, B. and R. LeB. Hooke. 2000. Glacier calving: a numerical model of forces in the calving-speed/water-depth relation. f. Glaciol., 46(153), 188-196.

Hunter, L. E., R. D. Powell and D. E. Lawson. 1996. Flux of debris transported by ice at three Alaskan tidewater glaciers. F. Glaciol., 42(140), $123-135$.

Josberger, E. G. 1978. A laboratory and field study of iceberg deterioration. In Husseiny, A. A., ed. Iceberg utilization. New York, Pergamon Press, 245-264.

Josberger, E. G. and S. Neshyba. 1980. Iceberg melt-driven convection inferred from field measurements of temperature. Ann. Glaciol., 1, 113-117.

Kirkbride, M. P. and C. R. Warren. 1997. Calving processes at a grounded ice cliff. Ann. Glaciol., 24, 116-121.

Mathews, J. B. and A.V. Quinlan. 1975. Seasonal characteristics of water 
masses in Muir Inlet, a fjord with tidewater glaciers. 7. Fish. Res. Board Can., 32(10), 1693-1703.

Meier, M. F., L. A. Rasmussen, R. M. Krimmel, R.W. Olsen and D. Frank. 1985. Photogrammetric determination of surface altitude, terminus position, and ice velocity of Columbia Glacier, Alaska. U.S. Geol. Suro Prof. Pap. 1258-F.

Motyka, R. J., L. Hunter, K. A. Echelmeyer and C. Connor. 2003. Submarine melting at the terminus of a temperate tidewater glacier, LeConte Glacier, Alaska, U.S.A. Ann. Glaciol., 36 (see paper in this volume).

Purdie, J. and B. Fitzharris. 1999. Processes and rates of ice loss at the terminus of Tasman Glacier, New Zealand. Global Planet. Change, 22(1-4), 79-91.

Russell-Head, D. S. 1980. The melting of free-drifting icebergs. Ann. Glaciol., 1, 119-122.

Van der Veen, C. J. 2002. Calving glaciers. Prog. Phys. Geogr., 26(1), 96-122.
Warren, C. R. and M. P. Kirkbride. 1998. Temperature and bathymetry of ice-contact lakes in Mount Cook National Park, New Zealand. $\mathcal{N} \cdot \mathcal{Z} . \mathcal{F}$. Geol. Geophys., $41(2), 133-143$

Warren, C. R. and M. P. Kirkbride. 2003. Calving speed and climatic sensitivity of New Zealand lake-calving glaciers. Ann. Glaciol., 36 (see paper in this volume).

Warren, C. R., N. F. Glasser, S. Harrison, V. Winchester, A. R. Kerr and A. Rivera. 1995a. Characteristics of tide-water calving at Glaciar San Rafael, Chile. f. Glaciol., 41(138), 273-289. (Erratum: 41(139), p. 281.)

Warren, C. R., D. R. Greene and N. F. Glasser. 1995b. Glaciar Upsala Patagonia: rapid calving retreat in fresh water. Ann. Glaciol., 21, 311-316. Weeks, W. F. and W. J. Campbell. 1973. Icebergs as a fresh-water source: an appraisal. f. Glaciol., 12(65), 207-233. 